\title{
The potential of elicited imitation for oral output practice in German L2
}

\author{
Frederik Cornillie ${ }^{1}, K_{\text {Kristof Baten }}^{2}$, and Dirk De Hertog ${ }^{3}$
}

\begin{abstract}
This paper reports on the potential of Oral Elicited Imitation (OEI) as a format for output practice, building on an analysis of picture-matching and spoken data collected from 36 university-level learners of German as a second language (L2) in a web-based assessment task inspired by Input Processing (VanPatten, 2004). The design and development of OEI for output practice faces two key challenges: learners must be engaged in meaningful language processing rather than in mere repetition of oral stimuli, and the task must eventually provide individualized and qualitative corrective feedback that helps learners to notice gaps between their interlanguage and the target language. Results show that learners attended to meaning and that a commercially available speech recognition tool was able to transcribe learner speech remarkably well.
\end{abstract}

Keywords: computer-assisted practice, elicited imitation, speaking, morphosyntax, input processing, speech recognition technology.

\section{Introduction}

In many instructed foreign language learning contexts, opportunities for spoken practice with individualized feedback are scarce. A candidate task for such practice is OEI. In its most basic form, OEI requires learners to repeat oral stimuli (typically sentences) as exactly as possible. It has been mainly used for language assessment, building on the assumption that learners can only accurately repeat sentences they have comprehended and parsed, and will access corresponding mental representations (internalized lexicons and grammars) to reproduce the stimuli. Previous research has shown that OEI can measure implicit knowledge (Erlam,

\footnotetext{
1. KU Leuven \& imec, Kortrijk, Belgium; frederik.cornillie@kuleuven.be

2. Ghent University \& FWO Vlaanderen, Ghent, Belgium; kristof.baten@ugent.be

3. KU Leuven \& imec, Kortrijk, Belgium; dirk.dehertog@kuleuven.be
}

How to cite this article: Cornillie, F., Baten, K., \& De Hertog, D. (2017). The potential of elicited imitation for oral output practice in German L2. In K. Borthwick, L. Bradley \& S. Thouësny (Eds), CALL in a climate of change: adapting to turbulent global conditions - short papers from EUROCALL 2017 (pp. 86-91). Research-publishing.net. https://doi.org/10.14705/ rpnet.2017.eurocall2017.694 
2009) and oral proficiency (Tracy-Ventura, McManus, Norris, \& Ortega, 2014). Additionally, language technology researchers have shown that OEI tests can be automated through Automatic Speech Recognition (ASR) technology (Graham et al., 2008). These findings open opportunities for computer-assisted oral output practice.

However, two preconditions need to be fulfilled for OEI to be a useful task for output practice. First, OEI-based practice must engage learners in meaningful language processing, otherwise the risk is that learners simply parrot what they hear (Erlam, 2009). Therefore, the instructional design of OEI-based practice must rely on sound principles of L2 teaching and learning. Secondly, the task must give automated corrective feedback that can help learners to notice gaps between their speech and the target language. This requires language technology that can accurately recognize learner speech and detect mismatches between learner output and the target language.

The current study investigated the potential of automating OEI for output practice in German L2 while taking these two requirements into account. Research questions include:

- Did the participants attend to meaning?

- How accurately does a state-of-the-art ASR transcribe the participants' production?

\section{Method}

We designed and developed a web-based and meaning-focused OEI test inspired by Erlam's (2009) implementation of OEI as well as by VanPatten's (2004) theoretical framework of Input Processing. Learners were required to choose between competing visual representations of the oral stimulus before speaking. Immediately after the oral stimulus, two pictures were shown, visualizing alternative interpretations of the stimulus (see Figure 1). This served two purposes: pairing oral stimuli with pictures would stimulate syntactic and semantic processing. Secondly, inserting the picture-matching between the listening and speaking phases results in a time interval, potentially 'flushing' learners' auditory working memory. This is a critical design choice if we do not want learners to draw on their short-term memory when speaking but rather on their internalized lexicon and grammar. 
Figure 1. Pictures representing competing interpretations of the ungrammatical stimulus *Der Mann gibt die Frau den Apfel

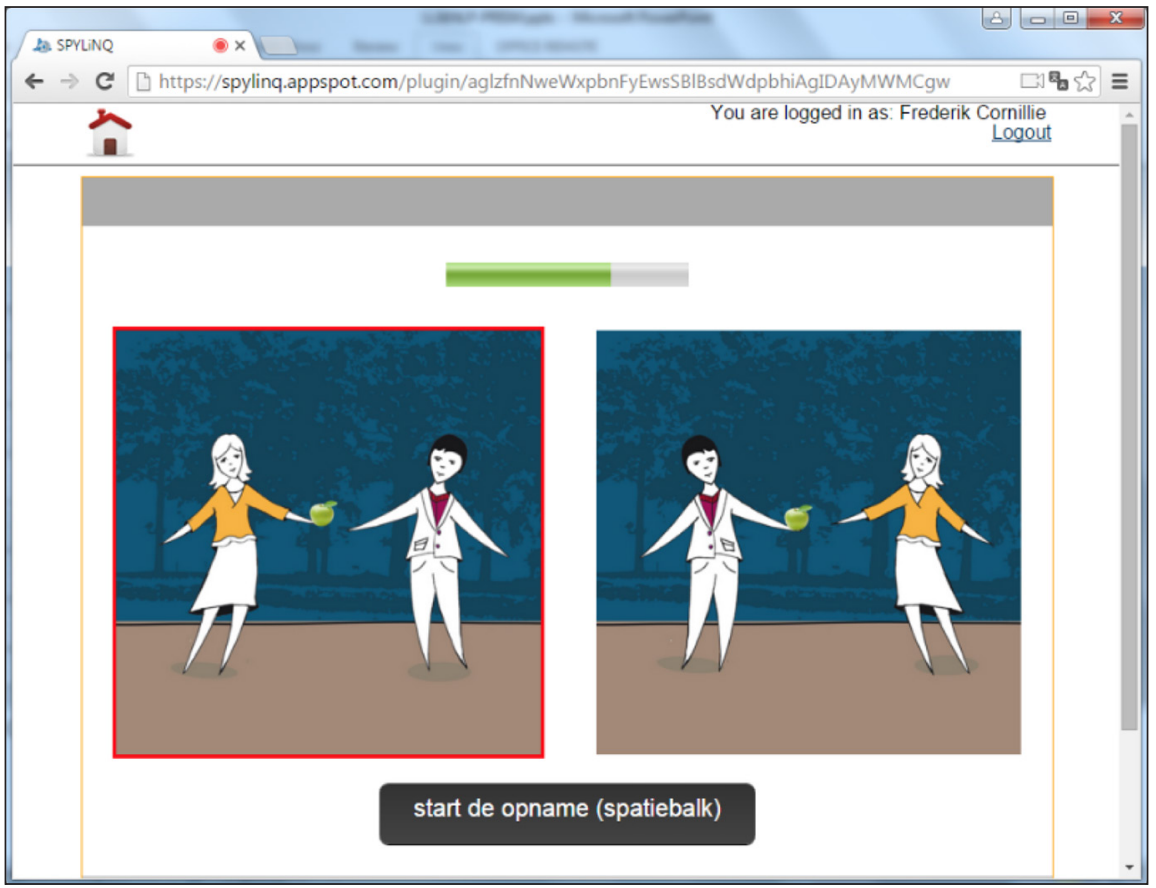

Picture-matching data and spoken data were collected from 36 university-level learners of German L2. Eleven students were in their second year of the academic bachelor program in languages, ten in the third bachelor year, and 15 in the master's program. Their level of proficiency according to the Common European Framework of Reference for languages (CEFR) was estimated between B2 and C1. Eleven students had had an Erasmus stay in a German-speaking country.

Each student was presented with 48 stimuli (comprising grammatical and ungrammatical sentences) that aimed to assess knowledge of case marking and word order; 16 sentences focused on transitives (e.g. Der Hund verfolgt den Mann, 'the dog chases the man'), 16 on ditransitives (e.g. Die Lehrerin schenkt dem Direktor die Blumen, 'the teacher gives the headmaster flowers'), and another 16 on prepositional phrases (e.g. Der Mann spaziert durch den Tunnel, 'the man walks through the tunnel'). Length of the stimuli ranged between five and eight words. The software logged students' interpretations of the sentences; their speech was recorded with Audacity. Students wore headsets throughout the experiment. 
After the experiment, the speech data were transcribed manually and through Google's ASR software (Cloud Speech API). This ASR was selected because it is known to work relatively well, can be easily plugged into applications through its API, and recognizes over 80 languages and variants, allowing to scale the solution to other languages.

For the first research question, we analyzed scores on the picture-matching tasks (assessing meaning recognition). If the participants did not attend to meaning during the OEI task, average scores at about the chance level $(50 \%)$ could be expected. Also, higher-level students were hypothesized to have higher scores. Additionally, we assessed linguistic variation in the learners' responses through manual inspection of the corpus. If semantic variation occurred in addition to (morpho-)syntactic variation, then chances were higher that the learners had also processed the stimuli for meaning.

For the second research question, distance metrics were computed between the manually and automatically transcribed data. We used Levenshtein distance at the word level, which reflects the number of changed, inserted, or deleted words (for each response). As ASR performance may have been affected by the learners' linguistic level, mean Levenshtein distance per student was regressed on the students' year of study and their Erasmus experience.

\section{Results}

The average percentage of correct responses overall was 78\%. Students in the second bachelor year scored $78.1 \%$ on average, in the third year $74.4 \%$, and students in the master's program $80.3 \%$. A one-way ANOVA proved the difference between the groups insignificant $(F(2,33)=0.88, p=0.42)$.

Manual inspection of the corpus revealed instances of semantic variation (e.g. Der Mann ist gegen den Baum gefahren > Der Mann ist gegen den Baum gefallen), morphological variation (e.g. Die Lehrerin schenkt dem Direktor die Blumen > *Die Lehrerin schenkt den Direktor den Blumen), syntactic variation (e.g. Dem Direktor schenkt die Lehrerin die Blumen > Die Lehrerin schenkt dem Direktor die Blumen), and combinations of these (e.g. Dem Sohn zeigt der Vater die Brille $>$ *Der Vater schenkt der Junge den Junge die Brille). In addition, there were instances of self-correction (e.g. Das Mädchen kommt aus der Shop - dem Shop), disfluencies (e.g. Der Doktor verklauf verkauft dem Clown das Buch) and multiple repetitions of the sentence, with or without self-corrections (e.g. Die Frau gibt den Mann den Apfel. Die Frau gibt dem Mann den Apfel.) 
Levenshtein distance between the manually and automatically transcribed responses ranged between 0 (perfect recognition) and 6 (six words changed, inserted, or deleted). The mean was 0.55 and the median was 0 . Out of a total number of 1487 automatically transcribed responses, 979 had zero edit distance. The regression analysis did not reveal any effects of year of study or Erasmus experience $\left(F(3,27)=0.3917, p=.76\right.$, adjusted $\left.R^{2}=-0.06\right)$.

\section{Discussion and conclusions}

This study aimed to assess the potential of OEI for output practice in German L2. First, high scores on the picture matching task as well as instances of semantic variation in learner speech suggest that the assessment task stimulated meaningful language processing, even if it was constrained and rather form-focused.

Secondly, Google's ASR service performed remarkably well on the non-native speech. These results bode well for the further development of the task. However, it must be taken into account that the study was limited to higher-level students whose mother tongue is phonetically rather similar to the target language; lowerlevel students from different mother tongue backgrounds may speak less fluently or in more accented ways, potentially affecting ASR performance.

The next step will be to go beyond simple distance metrics and automatically detect the different types of linguistic variation in order to develop feedback modules for an implementation of this task for L2 practice. This will be done with a view to conducting an experiment that aims to examine the effect of automated feedback on accuracy, fluency, and perhaps complexity (lexical diversity).

\section{Acknowledgements}

We would like to thank MA student Wouter Vanacker for collecting and preparing the data.

\section{References}

Erlam, R. (2009). The elicited oral imitation test as a measure of implicit knowledge. In R. Ellis, S. Loewen, C. Elder, R. Erlam, J. Philp \& H. Reinders (Eds), Implicit and explicit knowledge in second language learning, testing and teaching (pp. 65-93). Multilingual Matters. 
Graham, C. R., Lonsdale, D., Kennington, C., Johnson, A., \& McGhee, J. (2008). Elicited imitation as an oral proficiency measure with ASR scoring. Proceedings of the 6th International Conference on Language Resources and Evaluation (pp. 1604-1610). http:// repository.dlsi.ua.es/242/1/pdf/409_paper.pdf

Tracy-Ventura, N., McManus, K., Norris, J. M., \& Ortega, L. (2014). "Repeat as much as you can": elicited imitation as a measure of oral proficiency in L2. In P. Leclercq, A. Edmonds \& H. Hilton (Eds), Measuring L2 proficiency: perspectives from SLA (pp. 143-166). Multilingual Matters.

VanPatten, B. (Ed.). (2004). Processing instruction: theory, research, and commentary. Lawrence Erlbaum Associates. 


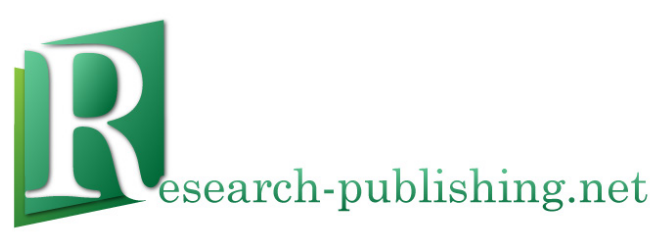

Published by Research-publishing.net, not-for-profit association Contact: info@research-publishing.net

(C) 2017 by Editors (collective work)

(C) 2017 by Authors (individual work)

CALL in a climate of change: adapting to turbulent global conditions - short papers from EUROCALL 2017 Edited by Kate Borthwick, Linda Bradley, and Sylvie Thouësny

Rights: This volume is published under the Attribution-NonCommercial-NoDerivatives International (CC BY-NC-ND) licence; individual articles may have a different licence. Under the CC BY-NC-ND licence, the volume is freely available online (https://doi.org/10.14705/rpnet.2017.eurocall2017.9782490057047) for anybody to read, download, copy, and redistribute provided that the author(s), editorial team, and publisher are properly cited. Commercial use and derivative works are, however, not permitted.

Disclaimer: Research-publishing.net does not take any responsibility for the content of the pages written by the authors of this book. The authors have recognised that the work described was not published before, or that it was not under consideration for publication elsewhere. While the information in this book are believed to be true and accurate on the date of its going to press, neither the editorial team, nor the publisher can accept any legal responsibility for any errors or omissions that may be made. The publisher makes no warranty, expressed or implied, with respect to the material contained herein. While Research-publishing.net is committed to publishing works of integrity, the words are the authors' alone.

Trademark notice: product or corporate names may be trademarks or registered trademarks, and are used only for identification and explanation without intent to infringe.

Copyrighted material: every effort has been made by the editorial team to trace copyright holders and to obtain their permission for the use of copyrighted material in this book. In the event of errors or omissions, please notify the publisher of any corrections that will need to be incorporated in future editions of this book.

Typeset by Research-publishing.net

Cover design based on (C) Josef Brett's, Multimedia Developer, Digital Learning, http://www.eurocall2017.uk/, reproduced with kind permissions from the copyright holder.

Cover layout by (C) Raphaël Savina (raphael@savina.net)

Photo "frog” on cover by (C) Raphaël Savina (raphael@savina.net)

Fonts used are licensed under a SIL Open Font License

ISBN13: 978-2-490057-04-7 (Ebook, PDF, colour)

ISBN13: 978-2-490057-05-4 (Ebook, EPUB, colour)

ISBN13: 978-2-490057-03-0 (Paperback - Print on demand, black and white)

Print on demand technology is a high-quality, innovative and ecological printing method; with which the book is never 'out of stock' or 'out of print'.

British Library Cataloguing-in-Publication Data.

A cataloguing record for this book is available from the British Library.

Legal deposit: Bibliothèque Nationale de France - Dépôt légal: décembre 2017. 